\title{
Using social media to increase the communicative competence of future specialists in the field of ecological tourism
}

\author{
Sergey Yekimov ${ }^{1, *}$, Tetiana Nepokupna ${ }^{2}$, Anzhela Shukanova ${ }^{2}$, Anton $_{\text {Ryabev }}{ }^{3}$, and \\ Maksym Tonkoshkur ${ }^{3}$ \\ ${ }^{1}$ Publishing House "Education and Science" s.r.o., Olstynska 607/1, Praha 8, 18100 , Czech \\ Republic \\ ${ }^{2}$ Poltava V. H. Korolenko National Pedagogical University, Poltava, Ukraine \\ ${ }^{3}$ National University of Urban Economy in Kharkiv Marshal Bazhanov street, 17, Kharkiv, Ukraine
}

\begin{abstract}
The article deals with issues related to the formation of communicative competence among graduates of higher educational institutions in the specialty "tourism". The importance of proficiency in foreign languages for further professional activities for future specialists in the field of eco-tourism is very high, and therefore there is a need to develop more effective methods of learning foreign languages. The use of social networks in teaching a foreign language allows you to make it more flexible and efficient, as well as more convenient for students . Easy learning increases motivation to learn a foreign language.
\end{abstract}

\section{Introduction}

The development of eco-tourism can contribute to solving regional economic and social problems, contribute to demographic stability, and contribute to filling the state budget.

In the process of engaging in eco-tourism, a person communicates with nature . Foreign travel companies offer their clients various types of tours related to visiting various natural complexes with a variety of fauna and flora. Visiting various national parks is very popular among tourists.

Ukraine, Belarus and the Russian Federation have vast territories and cultural monuments that are interesting for potential ecological tourists.

In the context of globalization, the geography of tourism has significantly expanded, and therefore it has become possible to attract tourists from different parts of the world.

In our opinion, the main problems of insufficient development of eco-tourism in the countries of the former USSR are, along with insufficient investment, imperfection of tourism legislation, as well as insufficient quality training of specialists in the tourism industry .

Many processes in tourism (booking tours, hotels, purchasing tickets are automated ) and the ability to establish business contacts with partners and communicate with tourists from different countries comes first.

*Corresponding author: 3701313@mail.ru 
Investments in tourism infrastructure will not have the desired effect if the service personnel working in the tourism sector do not speak at least one foreign language.

In our opinion, for the training of specialists who speak foreign languages, it is necessary not only to motivate them to learn languages , but also to create new more effective methods of learning.

The theoretical study of the problems of training specialists in the field of tourism services for interpersonal communication, at present, indicates the importance of studying the role of such elements as methods, forms and means of learning foreign languages in the linguodidactics of higher education, which contribute to the formation of future specialists' communicative competence in foreign languages.

$[1,2]$ in the modern globalized world, the level of development of international business contacts in the field of tourism, the creation of enterprises with foreign capital, the development of international integration in various spheres of public activity necessitates a good command of foreign languages as a communication tool for professionals of any profile , taking into account the characteristic features of the specialty or profession.

According to [3], the basis of higher professional education should be the model of the upcoming activity in the professional field. This condition determines the application of the principle of contextual modeling as the main principle that regulates the content component of the educational process.

A new level of interpersonal communication among professionals in the tourism industry causes, in our opinion, causes the need for transformational transformations of the entire system of professional training and the introduction of foreign language teaching, taking into account the specific features of the future profession.

According to $[4,5,6]$ for future professionals working in tourism, it is very important to form an appropriate understanding of their future profession, and the need to learn a foreign language, as well as the need for this to grow social and subject competence in order to further introduce them into the professional environment from educational activities.

According to [7] the use of the principles of contextual modeling of the social and subject component of the upcoming professional activity contributes to the emergence of a more adequate concept of the diversity of the spectrum of social and professional communications of a tourist industry employee, awareness of the main problems of his upcoming work and the acquisition of relevant practical experience.

For the successful formation of professional competencies, specialists in the tourism industry, such as: hotel managers, guides, travel agents , tour operators, airline personnel, have a need for communication skills in a foreign language .

Recently, more attention has been paid to the problems of learning foreign languages as a tool for communication interaction [8,9] however, currently the level of foreign language proficiency of graduates of non-language specialties of higher educational institutions does not fully meet the requirements of the labor market.

According to [10], the traditional approach to learning foreign languages based on the translation of texts in the studied specialty and memorization of lexical units has a number of disadvantages due to the presence of the following factors:

1) Insufficient use of foreign languages by students;

2) Requirements imposed by employers of interactive competence of students;

3) The need to optimize the organization of the educational process in teaching foreign languages, generalization of methodological tools and techniques designed to improve communication skills.

According to [11] the process of modeling the socio-subject aspect of the upcoming professional activity of students should be closely correlated with the application of a professional approach, since it requires determining the necessary list of skills, knowledge and skills, as well as the type of problems that are adequate for future professional activity 
in the field of tourism. adjustment of the content of the educational process of teaching foreign languages leads to an increase in the quality of tourist services.

According to $[12,13]$ professionally directed learning of foreign languages should provide for active interaction between all participants in the learning process, in the process of which communication skills are improved in relation to solving various professional problems.

According to [14] in the process of learning foreign languages, taking into account the professional bias, the methods and content of training should correspond to the prerequisites for the need for in-depth study of a foreign language. The following principles can be considered as a basis:

1) purposefully motivating the study of foreign languages;

2) Aspect-integrated approach to the learning process;

3) Professional Orientation of the educational process.

Among which, in our opinion, motivation is the most important.

It is defined by the need for study and research, the need to influence the environment, the need for self-realization, the need for interpersonal communication. If you do not adhere to the above principles of studying the principles of teaching foreign languages, the educational process will not be effective enough.

There are various methods of teaching and obtaining new knowledge, however, success in learning will be achieved, in our opinion, only if the trainees are motivated in this. Students, future specialists in the tourism industry, should be aware that learning foreign languages is not just adding to the vocabulary, obtaining the necessary set of knowledge that can be used in the future to search for information on the Internet, conducting business negotiations, etc.

According to [15] the organization of training sessions for the study of foreign languages should be based on the following principles:

1) The nature of the training should be active .

activation of conversational and mental activity is the key to successful study in tourism - Students should not just be able to write and read, but be able to use their cognitive abilities and knowledge of the world around them to navigate the flow of information.

2) Training should be developmental. when acquiring new knowledge, students should apply previously acquired knowledge. ;

3) The study of foreign languages should be regular and purposeful.

4) Students should experience positive emotions from the process of learning foreign languages, and the teacher, in turn, should provide all possible assistance to this.

\section{Methods}

In this research work, an analytical method was applied, through the use of which the problems studied in it were studied in their development and unity . taking into account the tasks and goals of the work done, the structural and functional method of scientific research was applied. This ultimately allowed us to study a number of problems related to the formation of communicative competence in future specialists of the tourism industry.

\section{Results}

Within the framework of this study, we studied the problem of motivation of foreign language learning by students of the specialty "Tourism" studying at the Dnipro National University. At the beginning of the study, we conducted a survey of students of 1-4 courses 
in which 364 students participated ( 1st year 98 people, 2nd year 97 people, 3rd year 88 people, 4th year 81 people) (Table 1).

Table 1. The results of a questionnaire survey to identify the motives for learning foreign languages.

\begin{tabular}{|l|c|c|c|c|c|}
\hline \multicolumn{1}{|c|}{ Motivations for learning } & \multicolumn{4}{c|}{ Number of students } & \multirow{2}{*}{$\begin{array}{c}\text { Total as } \\
\text { a percentage }\end{array}$} \\
\cline { 2 - 6 } & $\mathbf{1}$ & $\mathbf{2}$ & $\mathbf{3}$ & $\mathbf{4}$ & 70 \\
\hline $\begin{array}{l}\text { 1. To be educated and literate, a } \\
\text { person, as well as to expand their } \\
\text { erudition }\end{array}$ & 59 & 63 & 66 & 67 & 75 \\
\hline $\begin{array}{l}\text { 2. Learn to understand spoken foreign } \\
\text { language }\end{array}$ & 83 & 72 & 62 & 56 & 69.5 \\
\hline $\begin{array}{l}\text { 3. To communicate with foreign } \\
\text { business partners and tourists }\end{array}$ & 85 & 69 & 50 & 49 & 49.5 \\
\hline $\begin{array}{l}\text { 4. For the development of creative } \\
\text { independence in their future } \\
\text { professional activities }\end{array}$ & 35 & 40 & 48 & 57 & 41 \\
\hline $\begin{array}{l}\text { 5. To read foreign language literature } \\
\text { in order to improve knowledge of } \\
\text { tourism }\end{array}$ & 31 & 36 & 38 & 45 & \\
\hline
\end{tabular}

Based on the results of the survey, we conclude that most students start learning foreign languages at school. However, about $2 / 3$ of them , due to lack of proper motivation, lack of faith in success and underestimated assessment of their abilities and uncertainty of further professional career, interest in this decreases. while learning foreign languages as a means of achieving further professional growth, many students have additional incentives to overcome some psychological obstacles on this path, increasing interest in foreign languages, as well as motivation to study them.

In this study, we have divided the motivations for learning foreign languages into three groups.

In The first group we include Cognitive motives. The degree of cognitive motivation, according to our point of view, should be considered the most important factor that encourages learning.

Motives related to this group contribute to the active participation of students in the educational process, contribute to the appearance of positive emotions during training, help to manifest an emotional and cognitive attitude towards learning.

Students are interested in participating in educational activities, as well as learning foreign languages for the overall development of the individual.

In the second group, we attributed the motives associated with the presence of personal professional interest, characterized by the formed stable interest in learning foreign languages, based on the understanding of its importance in the future during professional activity. This attitude of students to the study of foreign languages is based on the emergence of a conscious understanding of the need to speak foreign languages for interpersonal communication .

About $3 / 4$ of all students who participated in the survey want to learn to understand foreign spoken language, and it should be noted that in junior years this indicator is higher than in senior years.

When conducting a detailed analysis of this group of motives, we conclude that with a sufficiently high level of motivation for direct contacts with the use of foreign languages with tourists and business partners for students of 1 year of study, 85 out of 98 people are engaged in learning foreign languages for this purpose. In the 3rd and 4th year of study, this indicator decreases slightly, which in our opinion can be explained with difficulties on the way to mastering foreign languages . 
However, if these students are given a real opportunity to communicate in foreign languages during industrial practices in health resorts and hotel complexes, this, in our opinion, will strengthen the effect of the motives of the second group. In the third group of motives, we distinguish the demands of society related to mastering the specialty. The main ones are, in our opinion, the possibility of communicating with foreign business partners and tourists using foreign languages $(69.5 \%)$, for the development of creative independence, in future professional activities (49.5\%), for reading foreign-language literature in order to improve knowledge of tourism (41\%).

Based on the analysis of this group of motives, we conclude that there are significant requirements of society for the possession of specialists working in tourism of appropriate competencies in the field of foreign language proficiency to use them during communication with tourists and business partners.

As information technologies develop, they are increasingly used in everyday life. Social networks have proven their effectiveness in the field of communication and information technologies and are very popular among students. In this regard, in our opinion the correct use of social networks for learning a foreign language will enhance the level of motivation of learners to participate in the educational process, will enable the implementation of training tailored to the individual characteristics of each student, reduce the degree of subjectiveness assessment of student knowledge and increase the level of availability of training materials. And the use of smartphones and tablets in the process of training will allow you to study in the most convenient place and time interval.Online multimedia tutorials, speech simulators, and specialized thematic sites will be widely used for teaching foreign languages.

The possibilities of social networks for use in the educational process allow for virtual contacts between students and teachers through video, voice and text messages

Social networks are special online services with the possibility of virtual communication and contact through written or video messages [1]. Social networks are very popular not only among young people, among users you can find people of different ages. In this regard, it is advisable to introduce the use of social networks in the educational process.

Communication in foreign languages contributes to the active consolidation of acquired new skills and abilities.Communication in social networks contributes to the earlier transfer of foreign students from the educational situation to the communicative situation, which ensures the active consolidation of knowledge, skills, and skills acquired in the classroom.

During the 2018/19 academic year, we conducted classes on learning a foreign language using social networks. At the end of the year, we conducted a survey of students on the effectiveness of using social networks to learn a foreign language.

The results of the survey showed that the use of social networks helped to reduce the psychological barrier, they communicated with each other and with the teacher in a foreign language with interest, this gave them the opportunity to believe in their abilities in mastering a foreign language.

\section{Discussion}

Ecotourism is becoming more and more popular from year to year. In this connection, there is a need for better training of future specialists working in the tourism industry.

In our opinion, one of the most important competencies of future specialists in the field of tourism is communicative competence.

In this regard, it is very important, along with increasing motivation to improve students' communicative competence, to develop more effective methods of learning 
foreign languages. the use of digital technologies and in particular social networks, in our opinion, make the learning process more fun and effective.

Based on the conducted research, we conclude that for the majority of students in the study group, understanding the need to acquire communicative competence in the field of foreign language proficiency corresponds to the basic professional requirements for employees of the tourism industry, and the presence of students' desire for a creative approach to learning foreign languages gives confidence in productive work on the formation of foreign language communicative competence.

But at the same time, in our opinion, there are opportunities to make the process even more effective . Given that students are not always sufficiently motivated to perform a particular task that teachers put before them, an active position of the teacher is required, which competently applies various ways of influencing the motivation of the student : the use of cases, an objective assessment of students ' knowledge , the problem content of tasks, etc.

The learning process focused on increasing the motivation of learning foreign languages, in our opinion, can be presented as a combination of various pedagogical technologies that make it possible to create conditions for the formation of communicative foreign language professional competence, among which the most effective can be thematic classes related to the upcoming professional activity.

\section{Conclusions}

To form the communicative competence of future specialists in the tourism industry, in our opinion, the training process should be built taking into account the following principles (Figure1) :

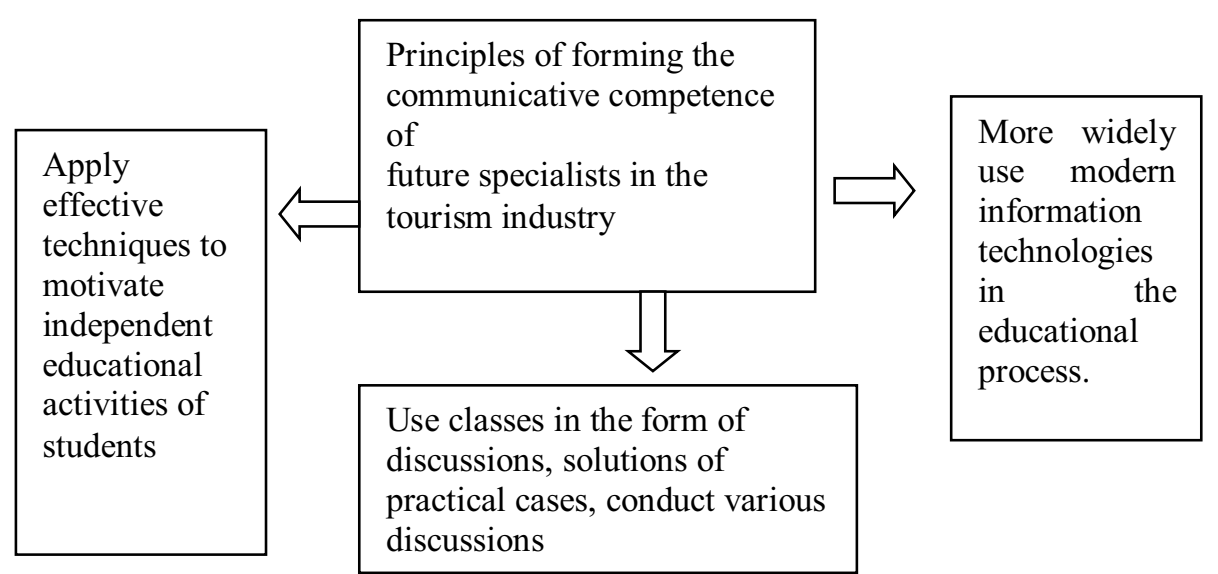

Fig. 1. Principles of forming the communicative competence of future specialists in the tourism industry.

\section{References}

1. E.L. Anchondo, European Scientific Journal ESJ 14(5), 184 (2018) https://doi.org/10.19044/esj.2018.v14n5p184

2. G. Angelova, Tourism Cadre. English Language Competence (South-West University "Neofit Rilsti" Publishig House, Blagoevgrad, 2020) 
3. A.J. Báez-García, F. Flores-Muñoz, J. Gutiérrez-Barroso, Tourism Review 73(3), 359373 (2018)

4. O. Baglay, Research on the intercultural competence of the future international tourism specialists, 54-55 (2020) https://doi.org/10.36074/10.07.2020.v2.09

5. N.V. Bitter, I.A. Kolupanova, I.V. Zhidkova, Pedagogics and psychology of education series (2015) doi: 1.10.18413/2313-8971-2015-1-2-5-10

6. G. Hasanova, M. Samandarova, Theoretical \& Applied Science 82, 574-579 (2020) doi:10.15863/TAS.2020.02.82.95

7. O.M. Honcharova, Innovate Pedagogy 19, $74-77$ (2019) doi: 10.32843/2663-60852019-19-1-16.

8. G. Korchagina, Value orientations as a component of the readiness of future specialists tourism to recreational and environmental activities (2018) doi: 10.18411/1j-08-201816. P.34-35

9. V. Maikovska, O. Semenog, Requirements analysis concerning entrepreneurial competence of future specialists in tourism in the context of national educational transformations, 663-669 (2020) DOI: 10.31617/k.knute.2020-06-01.93.

10. T. Melnyk, Formation of communicative competence in future specialists in tourism (MAUP, KIYV, 2019)

11. S. Menggo, I. Suparwa, I. Astawa, Hindering Factors in The Achievement of English Communcative Competence in Tourism Academy Students 31, 137-152 (2019) DOI: 10.29255/aksara.v31i1.235.137

12. N. Morozova, R. Kulichenko, V. Penkov, et al., The Advanced System Training Of A Competent Specialist. Tambov University Review. Series: Humanities, 7-13 (2018) DOI: $10.20310 / 1810-0201-2018-23-176-7-13$

13. Kh. Pletsan, Bulletin of Kyiv National University of Culture and Arts. Series in Tourism 2, 142-156 (2019) DOI: 10.31866/2616-7603.2.2.2019.189540

14. G. Rizakhojayeva, M.M. Akeshova, A.K. Rysbekova, et al., Man in India 97, 107-121 (2017)

15. Z. Sándorová, The Importance of Intercultural and Communicative Competences for Tourism Labour Market (2019) DOI: 10.4995/HEAD19.2019.9389 